\title{
THE REALIZATION OF PROSODIC CATEGORIES IN POLITICAL MEDIA DISCOURSE IN BRITISH AND AMERICAN LINGUACULTURES
}

\author{
Laurissa V. Milyaeva \\ Moscow Financial University under the Government of Russian Federation \\ (Moscow, Russia) \\ LVMilyaeva@fa.ru
}

\begin{abstract}
The main aim of the article is to describe, analyze and compare main prosodic categories that are realized in a unique context, namely in political media discourse. The article looks into the principles of classification of the prosodic categories as well as at realizational differences of three main prosodic categories: syllable, foot and intonation phrase. These categories are distinguished unanimously by the majority of the researchers and are described in the article form their structural and cognitive perspectives. The realizational differences of these categories derive from pragmatic and linguacultural features of English media communication. In the article media communication is represented with political media discourse which is understood as a new contextual model of media communication and is characterized by high degree of immediacy and interactivity. Certain attention in the article is given to the results of the comparative research of the realizational differences of the prosodic categories done by the author. On the basis of the data resulted from the prosodic and content analysis the author concludes that the realizational differences of the prosodic categories are often due to pragmatics of the discourse and the type of discourse itself.
\end{abstract}

Key words: prosodic categories, realizational differences, media discourse, political discourse, comparative analysis, phonology.

\section{INTRODUCTION}

The term "category" has been studied for a long time from different perspectives (philosophical, linguistic, sociological, etc.) and has got many different representations.

The term "category" in general scientific sense is the fundamental term that reflects sustainable and regular connections and relations between reality and experience or knowledge [Ozhegov, 1992; Yartseva, 1998]. Many researches show that categories in linguistics form a "closed" system where the members are united with one or several features and function as forms or sustainable principles of intellectual process [Yartseva, 1998; Akhmanova, 2007].

Everything mentioned above gives us the reason to assume that any category (regardless of the scientific approach from which it is studied) is of cognitive nature, as it reflects and enshrines human activity, experience and knowledge.

In this article our primary focus is on descriptive, theoretical and comparative analyses of prosodic categories that are actualized in political media discourse in two different linguacultures (British and American) united by one language.

\section{PROSODIC CATEGORIES AND PRINCIPLES OF THEIR CLASSIFICATION. LITERATURE REVIEW}

Following the results of different researches [Pierrehumbert \& Beckman, 1988; Pierrehumbert, 1980; Selkirk, 1978, 1986, 1995, 2005; Nespor \& Vogel, 1986; Gussenhoven, 
2004], we have grounds to claim that any language is characterized by a system of prosodic categories.

The system of prosodic categories is represented by the corpus of prosodic units. These units have one field of realization (i.e. phonological) and construct a unique and strong hierarchical system. The units may differ in their structure and realizational peculiarities associated with the language itself or with its invariants; they can also differ in their mandatory presence, i.e. languages may have different numbers of categories, and in their mandatory combinations.

The system of prosodic categories should be studied in close connection with the theory of prosodic structure of an utterance which is in the center of such scientific paradigm as prosodic phonology. Those researchers, who work in this scientific field, consider the flow of speech as an organized structure of phonological units; the above mentioned units interact with the units of grammar and vocabulary and in such a way build phonological structure of an utterance. Phonological structure of an utterance consists of levels that are structured hierarchically and these levels, in their turn, consist of the prosodic categories starting from the syllable and up to the phonological utterance.

The idea of a phonological structure of an utterance was first mentioned in the works of Firth in the 1930s and later his ideas and the ideas of his supporters and followers were dominating the field in the 60s. The theory received further development in the works of Liberman and Prince (1977) and then was adopted and developed by Selkirk $(1978,1986)$, Pierrehumbert (1980), Pierrehumbert and Beckman (1988), Nespor and Vogel (1986), Ladd $(1980,1986)$ and others.

In the works of the researchers mentioned above we find claims that every utterance (as well as every word) possesses its own phonological structure. Thus, the main assumption of the prosodic structure theory may sound as following: phonological representation of an utterance can be viewed as a structure that consists of distinct prosodic units. These prosodic units form a hierarchy where at the base there is the smallest prosodic unit (a syllable) and at the top there is the unit of the highest level or an utterance (IP or U) [Selkirk, 1978, 1986; Pierrehumbert, 1980; Pierrehumbert \& Beckman, 1988; Nespor \& Vogel, 1986; Wheeldon, 2000; Buring, 2016].

In the works of Gussenhoven (2005) we find the ideas of prosodic structure of an utterance presented in a well-designed scheme which contains six elements. Let us present this scheme in our article to make it more graphic [Gussenhoven, 2005]:

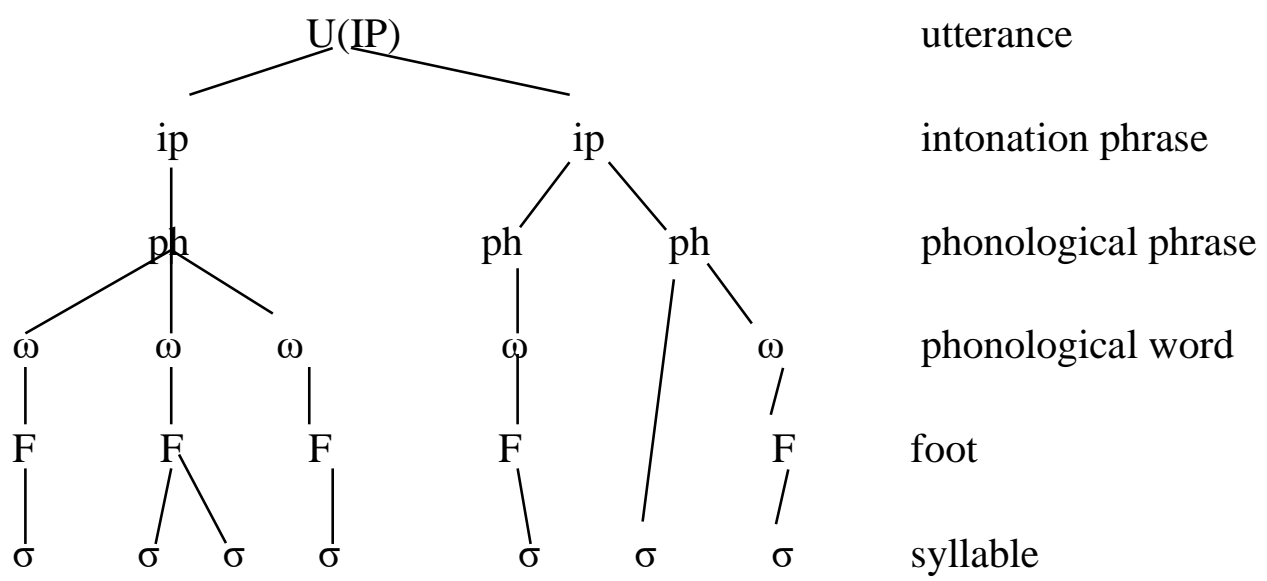


Taking into account everything mentioned above, we find it possible to make an assumption: prosodic units that form phonological model of an utterance should be viewed as universal phonological categories. Therefore, accepting the terminology of recent phonological researches [Beckman, 1986; Hirst \& Di Cristo, 2004; Jun, 2006; Gussenhoven, 2004; Selkirk, 1995; Pierrehumbert \& Beckman, 1988] under prosodic categories we would understand a "syllable", a "foot", a "phonological word", a "phonological phrase" and an "intonation phrase", known in traditional terminology as a "syllable", an "accent group", a "rhythmic group" and a "syntagma" respectively [Shakhbagova, 1982, 1992; Antipova, 1980, 1984; Vasilyev, 1980; O’Connor \& Arnold, 1973].

All these categories are universal and exist and function in all the languages and are characterized by realizational differences. It is worth mentioning that such category as an "utterance" is quite controversial as there is not enough data concerning it in scientific literature. Thus, it can't be ranked as a universal category. Further in the article we will deal only with three main categories: "syllable", "foot" and "intonation phrase".

Our analysis of the works of different researchers, who work in the field of phonology and study phonological categories, allow us to highlight some common characteristics that researches kept under review while allocating and describing prosodic categories [Selkirk, 2003; Gussenhoven, 2005]:

- $\quad$ structural layout of the category - structure and size of the category should be taken into consideration;

- functionality - place and function of the category in the system;

- cognition - cognitive character and features of the category.

\subsection{A closer description of the categories}

The prosodic category "syllable" as a phonological unit in the majority of modern researches is viewed as a minimal articulatory group which is the unity of phoneme combinations with a vowel as a nucleus and a certain amount of consonants surrounding it in the variety of combinations allowed by the language itself [Durand \& Laks, 2004; Buraya, Galochkina \& Shevchenko, 2006; O'Connor \& Trim, 1953, 2003).

The prosodic category "syllable" exists in all the languages and presents an important element of a spoken chain playing a vital role in the processes of speech production and speech perception. As the results of numerous researches show, the prosodic category "syllable" is universal, i.e. it exists in the phonological system of all languages, and possesses universal characteristics. To such characteristics we may refer the following:

- open syllable structure (VC - vowel + consonant) is considered basic in the majority of languages;

- all the segmental units are grouped into syllables according to the degree of sonority which is reflected in the syllabic structure. It means that the most sonorous element would be found in the center of a syllable (would occupy the position of a nucleus) and all other elements would be positioned around it according to the same degree of sonority: the less sonorous the element is - the farther it is from the nucleus; 
- polysyllabic words are divided into syllables according to the principle of the "maximal onset" [Durand \& Laks, 2004; Buraya, Galochkina \& Shevchenko, 2006].

In all our researches [Postnikova, 2011, 2014] and other works devoted to the prosodic categories attention is always drawn to the fact that any prosodic category is also a cognitive category. The cognitive character of any category is revealed in its ability to reflect the connections between reality and experience or cognition. From the cognitive point of view, the prosodic category "syllable" is viewed as a unique mental structure meaningful for speech production and speech perception [Sequi \& Ferrand, 2002; Ferrand, 1995; Durand \& Larks, 2002].

Modern cognitive phonological researches suggest two main approaches to the category under discussion as to cognitive phonological unit. According to the first approach, syllables are accepted as solid unitary chunks. It gives evidence to the fact that the words are stored in our mental lexicon as sequences of syllables and every syllable is represented by one symbol which comes as its sound representation. From the point of view of the second approach, "syllables" should be perceived as certain schemes. These schemes only determine the structure of a syllable and have nothing to do with its phonological representation as the latter possesses its own cognitive representation [Ibidem].

Following everything mentioned above, we may assume that according to the first approach such syllables as [sit] or [bed] represent different chunks as the sounds, which they are comprised of, are absolutely different; but from the second point of view they are equal as they possess a common structure ( $\mathrm{CVC}$ - where $\mathrm{C}$ is a consonant and $\mathrm{V}$ is a vowel) [Ibidem].

All the facts, previously referred to, prove the statement that the phonological status of the prosodic category "syllable" still remains open and gives grounds for discussion; the results of different researches of different scholars do not give sustainable and complete data that would allow to accept one of the viewpoints as the correct.

Under the influence of stress syllables are grouped in to a prosodic unit of a greater magnitude and form a stress group or the prosodic category which is in modern terminology gets the name "foot" [Abercrombie, 1964; Halliday, 1970; Gussenhoven, 2005].

From the structural point of view, the prosodic category "foot" is the category that consists of the succession of two syllables one of which is strong (stressed or S) and the other one is weak (unstressed or Us) [Gussenhoven, 2005; Hayes, 1995; Selkirk, 1980]. There are two main models of the category "foot" based on its structural differences that can be presented in the following schemes: "S - Us" and "Us - S". As we can see, these models differ according to the position of the stressed syllable and these models function in the phonological systems of all the existing languages. Typical "foot" is formed out of two syllables but polysyllabic and monosyllabic "feet" are not a rare thing. It is monosyllabic "foot" that presents a sticking-point and gets different construal in the works of different phonologists. Thus, some linguists are sure that monosyllabic "foot" consists a priory of a stressed syllable, while others deny its existence at all and view it as a binary structure with an "empty" structural element [Ibidem].

From the functional perspective the prosodic category "foot" is the category on which the English rhythm is based. And this fact is important for the analysis of the tempo. The latest researches revealed one more important feature of the category "foot". According to these researches "foot" is the category which is the home for different tonal changes; in earlier researches such changes were associated only with stressed syllables [Hirst \& Di Cristo, 2004].

The prosodic category "intonation phrase" is in itself the largest prosodic category in the phonological structure of an utterance and is intonationally marked. It gets different 
"names" in the works of different scientists: nominal phrase, sense group, prosodic unit that contains no pauses, intonation group, etc.

As the works of different scientists show, the most important questions to answer while analyzing the "intonation phrase" is the question of its size and its borders. The main dispute goes around the following: how far the size and the length of the "intonation phrase" depend on pragmatics, syntax and semantics of the discourse. If not to go to extremes, we may suppose that pragmatics plays the leading role in the division of the utterance into intonation phrases. But we can't ignore some basic syntactic constraints, such as the tendency of intonation phrases to coincide with simple sentences or subordinate clauses [Ibidem].

The length of the intonation phrase can be measured in syllables or words. But such approach is not accurate at all as a lot depends on the structure of a syllable itself, on the functional words and their position in this prosodic category. The researches of J. Jun (a famous phonologist of Seoul University) proved that the most effective way to measure the prosodic category "intonation phrase" is in milliseconds (further $m s$ ) [Jun, 2006].

According to the data presented in scientific literature the average length of an intonation phrase reaches 1,5 ms (in English, German and French). But we should always remember that such factors as the type of a discourse and style genre of speech influence the length of intonation phrases and, thus, should always be taken into account while analyzing intonation phrases [Postnikova, 2014].

\section{RESULTS OF THE RESEARCH}

Comparative analysis of the prosodic categories in political media discourse, which is presented in this article, was carried out based on the authentic empirical material of political discourse in two variants of the English language: the British variant (henceforth BE) and the American variant (henceforth AE). Political discourse is represented by the political shows and programs of the BBC channel. Here we should mention once again that in this article we present the analysis of the three main categories "syllable", "foot" and "intonation phrase" that are allocated as universal categories by the majority of scientists.

Now, let us pass over directly to the analysis of the particular realizational differences (features) of prosodic categories in media political discourse in $\mathrm{BE}$ and $\mathrm{AE}$.

The results of the comparative analysis of prosodic categories in political media discourse in two main variants of English, as well as the unity of the phonological systems of these two variants, gave us the grounds to claim that British and American linguacultures possess a common system of prosodic categories [Postnikova, 2003, 2005, 2012, 2014]. And therefore, we should mention that prosodic form of conversational behavior is reflected not only in prosodic structure of an utterance but is also shaped by social and psychological roles of communicators, by their "roles" and individual and personal relations in formal and informal communicative situations, that is to say by specific characteristics of the "speaking etiquette" in the society. All these things influence the specific realization of prosodic categories in English coherent discourse.

Realizational differences in the system of prosodic categories are nationally specified and revealed through acoustic data and specific character of melodic configurations of the sounding discourse. 


\subsection{Prosodic category "syllable"}

In media political discourse in the British variant of English such prosodic category as "syllable" (namely stressed syllable) is characterized by equal presence of rising-falling tones and falling tones of narrow range (3-4 semitones) with the maximum results of $F_{0}$ up to $221 \mathrm{~Hz}$. Alongside with this the prosodic category "syllable" is illustrated by quite high indices of length. Average Length of Syllable (further ALS) of a stressed syllable is $200 \mathrm{~ms}$ but can amount up to $270 \mathrm{~ms}$. It proves a certain tendency in the realization of this category in British political media discourse. We shall call this tendency - lengthening of a stressed syllable in media political discourse.

In American media discourse ALS of a stressed syllable is much shorter and on average amounts up to $147 \mathrm{~ms}$. Stressed syllables are mainly characterized by Rising tone of narrow range and quite high indices of $\mathrm{F}_{0}$. But these indices are still lower than in the British variant: $\mathrm{F}_{0 \text { max }}$ is $183 \mathrm{~Hz}$ and $\mathrm{F}_{0 \text { min }}$ is $166 \mathrm{~Hz}$.

To sum up, the results of the comparative analysis allow us to state the fact that the prosodic category "syllable" in political media discourse in both variants of the English language (BE and $\mathrm{AE}$ ) may be characterized by the following:

- domination of rising termination on the stressed syllables;

- the range of $\mathrm{F}_{0}$ is quite narrow;

- the indices of $F_{0}$ are not high.

Nevertheless, the indices of ALS of the prosodic category "syllable" in the American variant are much lower than in British English and it gives evidence to the fact that the rate of speech in American political media discourse is higher, that is to say, American politicians, statesmen and political newsmen speak quicker compared to their counterparts in British English.

In the chart below you may find the averaged key indices of the prosodic category "syllable":

\begin{tabular}{|c|c|c|}
\hline Prosodic category "syllable" & British Variant & American Variant \\
\hline \multicolumn{3}{|c|}{ Political Media Discourse } \\
\hline Tone Termination & $\begin{array}{ll}\text { 1. } & \text { Rising-Falling } \\
\text { 2. } & \text { Falling }\end{array}$ & Rising \\
\hline ALS & $200 \mathrm{~ms}$ & $147 \mathrm{~ms}$ \\
\hline $\mathrm{F}_{0 \max }$ & $197 \mathrm{~Hz}$ & $183 \mathrm{~Hz}$ \\
\hline $\mathrm{F}_{0 \min }$ & $163 \mathrm{~Hz}$ & $166 \mathrm{~Hz}$ \\
\hline Tone Range & $3-4 s t$ & 4 st \\
\hline
\end{tabular}

Chart 1

So, reviewing the results and summarizing everything mentioned above we may note the following: realizational differences of the prosodic category "syllable" in political media discourse in two main variants of the English language show similar tendencies. First of all, it can be seen in the figures of the range of $\mathrm{F}_{0}$ (in both linguacultures the range of the stressed syllable is narrow) and in the terminations of tones, realized on a syllable (in both variants we observe the presence of falling termination). The main realizational difference lies in the figures of ALS which are much higher in the American variant and prove the fact that political media discourse in the American variant of English is characterized by a faster rate of speech. 


\subsection{Prosodic category "foot"}

Let us start with the consequence. The comparative analysis of the prosodic category "foot" revealed certain realizational differences of this category in political media discourse of the two national variants of the English language.

In the American variant of the English language in media political discourse the prosodic category "foot" is characterized by a certain set of melodic configurations: Level Tones, Falling Tones and Falling-Rising Tones. However, dominating positions are occupied by Level Tones. Alongside with this, prosodic category "foot" with level termination of melodic configurations is noted for high indices of $\mathrm{F}_{0}\left(\mathrm{~F}_{0 \max }\right.$ reached the level of $\left.245 \mathrm{~Hz}\right)$ as well as for the narrowest range of $\mathrm{F}_{0}$ - only 4 st. "Feet' with prevailing falling termination are registered mainly in the initial and final intonation phrases. Falling Tone in such "feet" has the widest range of $F_{0}(8 \mathrm{st})$ and the highest figures of $F_{0 \max }$ that may reach $275 \mathrm{~Hz}$. "Feet", on which the Falling Tones are realized, are the longest, it means that the figures of average length reach $257 \mathrm{~ms}$. In general, it is worth noting that in media political discourse in the American variant the prosodic category "foot" is marked by an increase in length and by widening of the range.

In British political media discourse the situation is somehow different. To the dominating tones we may refer the following tones: Level Tone (the same as in American variant) and Falling Tone. From the point of view of realizational differences the prosodic category "foot" is characterized by the following:

- the "foot" is noted for the increase in length;

- the range tends to widen;

- the figures of $\mathrm{F}_{0}$ are getting higher.

In the following chart below, one may find the averaged exponents for the prosodic category "foot" in British media political discourse:

\begin{tabular}{|c|c|c|c|}
\hline $\begin{array}{c}\text { Averaged length of a } \\
\text { "foot", ms. }\end{array}$ & $\mathrm{F}_{\text {0max }}(\mathrm{Hz})$ & $\mathrm{F}_{\text {0min }}(\mathrm{Hz})$ & $\begin{array}{c}\text { Averaged range } \mathrm{F}_{0}, \\
\text { semitones }\end{array}$ \\
\hline 158 & 213 & 157 & 6 \\
\hline
\end{tabular}

Chart 2

Let us draw some conclusions. So, in media political discourse the prosodic category "foot" in both British and American variants of the English language is characterized by certain tonal structures and melodic configurations (depending on the pragmatics of the utterance). The range of $F_{0}$ is narrow and the indices of $F_{0}$ are not very high. But, at the same time, we can't ignore some tendencies that develop in the prosodic category "foot" in political media discourse. First of all, it is the length. In this type of a discourse the prosodic category "foot" is noted for the tendency to lengthen in both variants of English. The second is the range of $\mathrm{F}_{0}$. In general, in both variants the range of the prosodic category "foot" can be considered narrow, but the results of the research show that in both variants the range tends to widen. The third tendency that is worth mentioning is the variation of $\mathrm{F}_{0 \max }$. In both variants of English there is a tendency to serious increase in the figures of $\mathrm{F}_{0 \max }$ in media political discourse in both variants 
of English. Thus, in British English it reaches $213 \mathrm{~Hz}$ and in American English is amounts to $245 \mathrm{~Hz}$. Looking ahead, we should note that the tendency for the range to widen in media discourse is observed with such prosodic category as "intonation phrase".

Speaking about the realizational differences of such prosodic category as "intonation phrase" in both variants of English, we are bound to mention that the research revealed two opposite tendencies in media political discourse in both linguacultures.

Indeed, in British media discourse there is a tendency to the increase of all the prosodic indices of the category under consideration (that is "intonation phrase"). We have to admit that the increase in the length of "intonation phrase" itself came as the most unexpected. The same should be noted for the pausation (pauses became longer in media discourse in contrast with an institutional one, for example). As a result, the tempo of the "intonation phrase" (the rate of its pronunciation in milliseconds) came as rather slow if to compare with institutional discourse, for instance.

The prosodic category "intonation phrase" in political media discourse in British English is characterized by rather wide range of $F_{0}$ and high indices of $F_{0}$.

In the American variant we observe quite an opposite tendency - the tendency for the prosodic indices to decrease. In media political discourse, the prosodic category "intonation phrase" is indicative of shorter length, higher tempo and short length of final pauses. But it should be noted that the indices of $F_{0}$ and of the range of $F_{0}$ remain practically unchanged.

Summing everything up, we may well assume that the prosodic category "intonation phrase" is noted for serious variations in prosodic indices in both variants of English and it can be explained by a number of reasons. Here should be noted the commitment of the British to the formal public speaking traditions and high level of speech expressiveness. In media discourse the way of presenting information is specified by the strict time limits and it influences the realization of prosodic categories.

Now it can be seen that the comparative analysis of the prosodic categories in two different linguacultures allows distinguishing universal features of the prosodic categories and nationally-marked peculiarities of the categories in the British and American variants of English. Universal character of the prosodic categories manifests itself in the indices of $\mathrm{F}_{0}$ : narrow range of $F_{0}$ and not very high $F_{0 \max }$ of such categories as "syllable" and "foot" in institutional discourse. This can be explained by the unity of the phonological system and of the rhetorical practices. Universalism is seen in the tendency of the range to widen in such categories as "foot" and "intonation phrase" in media discourse.

Realizational versatility of the prosodic categories, caused by the type of political discourse, is seen in the indices of $F_{0}$ and length and very explicitly seen in British political linguaculture. Thus, in media discourse in BE there is a tendency to the increase in length and to the widening of the $\mathrm{F}_{0}$ range of all the prosodic categories.

In American media discourse such changes also take place but they manifest themselves not so vividly and it speaks for the fact that American political discourse tends for stable realization of the prosodic categories despite the type of political discourse.

\section{CONCLUSION}

Finishing this article, we find it possible to come to certain conclusions and findings. First of all, we should state that modern phono-stylistic researches and the results of our own research give evidence and firmly prove the fact that prosody itself and the prosodic categories as its integral part are the finest indicators of rhetorical persuasive means used by speakers to 
influence the minds and emotions of listeners and the audience. These means are carefully chosen in accordance with the communicative situation and the image of the speaker.

The results of our experimental research also prove that British and American political discourses possess common prosodic characteristics that are intrinsic of English political culture as a whole; but at the same time we have all the grounds to claim that in two different linguacultures united by one language one may find such differences which are due to sociocultural factors: different types of discourse, political context of the situation, differences in the mentality, etc.

Analyzing any political discourse at every level of the linguistic system, a researcher gets the possibility not only just to study and describe all the forms and categories that function on the surface but also to get the results and come to conclusions that are based on linguistic interpretation and processing.

\section{REFERENCES}

1. Akhmanova, O.S. (2007). Slovar' lingvisticheskih terminov [The dictionary of the linguistic terms]. Moscow: URSS (in Russian).

2. Buraya, E.A., Galochkina, I.E., \& Shevchenko, T.I. (2006). Fonetika sovremennogo anglijskogo jazyka. Teoreticheskij kurs [Phonetics of the modern English language. Theoretical course]. Moscow: Academy (in Russian).

3. Durand, J., \& Laks, B. (2004). Phonetics, phonology and cognition. Oxford: University Press.

4. Firth, J.R. (1935). The technique of semantics. Transactions of the philological society, 36-72.

5. Gussenhoven, C. (2005). The phonology of tone and intonation. Cambridge: Cambridge University Press.

6. Hayes, B. (1995). Metrical theory. Chicago: Chicago University Press.

7. Hirst, D., \& Di Cristo, A. (2004). Intonation systems. A survey of twenty languages. Cambridge: Cambridge University Press.

8. Jun, J. (2006). Prosodic typology. The phonology of intonation and phrasing. New York: Oxford University Press.

9. Ladd, D.R. (1980). Stylized intonation. Language, 54, 517-540.

10. Ladd, D.R. (1981). On intonational universals. In T. Myers et al. (Eds.). The cognitive representation of speech (389-397), Amsterdam: North Holland Publishing.

11. Ladd, D.R. (1996). Intonational phonology. Cambridge: Cambridge University Press.

12. Lieberman, P. (1967). Intonation, perception, and language. Cambridge, MA: MIT Press.

13. Pierrehumbert, J. (1979). The perception of fundamental frequency declination. The journal of the acoustical society of America, 66(2), 363-369.

14. Pierrehumbert, J.B. (1980). The phonetics and phonology of English intonation (PhD thesis). Massachusetts Institute of Technology, Massachusetts, the USA.

15. Pierrehumbert, J.B., \& Beckman M.E. (1988). Japanese tone structure. Cambridge, MA: MIT Press.

16. Pierrehumber, J., \& Hirschberg, J. (1990). The meaning of intonation contours in the interpretation of discourse: intentions in communication. Cambridge, Mass: MIT Press. 
17. Postnikova, L.V. (2011). Prosodija politicheskogo diskursa v britanskoj i amerikanskoj lingvokul'turah [Prosody of political discourse in British and American Linguacultures]. Moscow: Librokom (in Russian).

18. Postnikova, L.V. (2012). Britanskij kommunikativnyj stil' v prosodii politicheskoj rechi [British communicative style in the prosody of political speech]. Kul'tura ustnoj rechi [Spoken language culture], Moscow: Rema, 18(651), 92-103 (in Russian).

19. Selkirk, E. (1978). On prosodic structure and its relation to syntactic structure. In Th. Fretheim (Eds.). Nordic prosody II (268-271), Trondheim: TAPIR.

20. Selkirk, E. (1986). On derived domains in sentence phonology. Phonology Yearbook 3, 371-405.

21. Selkirk, E. (2005). Comments on intonational phrasing in English. In S. Frota, M. Vigário \& M.J. Freitas (Eds.). Prosodies (11-58), Berlin: Mounton de Gruyter.

22. Yartseva, V.N. (1998). Lingvisticheskij jenciklopedicheskij slovar' [Unabridged encyclopedic dictionary]. Moscow: Sovetskaya Encyclopedia (in Russian).

\section{How to cite this article:}

Milyaeva, L.V. (2020). The realization of prosodic categories in political media discourse in British and American linguacultures. Professional Discourse \& Communication, 2 (2), 10-19. https://doi.org/10.24833/2687-0126-2020-2-2-10-19

\section{(c) ()}

This work is licensed under a Creative Commons Attribution 4.0 International License. 